\title{
Life saving healing of an impossible wound
}

\author{
Andrew Hague* \\ Professor of Advanced Medicine, President, Cellsonic, Manufacturers of Medical Equipment, UK
}

The use of lithotripsy for wound healing was discovered late last century. It taught us about the generation of soft tissues, vascularisation and growth of nerves. In fact, a wound as big as that shown in the video is more than wound healing, it is growing a new organ. More than just skin is formed. The new skin is sensitive; nerves are built in.

Understanding what happens when zapped by CellSonic pulses has opened up new areas of cure and as I write this, January 2018, we are looking at Parkinson's disease. Results are not yet known other than a certainty that there will be no harm. That fact allows us to start on a human patient, not in the lab or on rats. It is this important difference to drugs that makes CellSonic better; there are no side effects.

In some countries, most non-healing wounds are not caused by diabetes, they are the result of infections either from accidents to the patients or caused by surgery where anti-biotics failed. The CellSonic VIPP will stop (kill) all and any infection wherever it is. Note that wounds heal from underneath upwards, not from the top downwards. This means that whatever is put on a wound can be useless. The removal of infection and increasing the blood supply to deliver more oxygen, white cells and stem cells has to be done inside the body, beneath the wound and well around.

Copyright: ( $\mathrm{C} 2018$ Hague A. This is an open-access article distributed under the terms of the Creative Commons Attribution License, which permits unrestricted use, distribution, and reproduction in any medium, provided the original author and source are credited.
Correspondence to: Andrew hague, Professor of Advanced Medicine, President, Cellsonic, Manufacturers of Medical Equipment, UK, Tel: +1 3152106307 ; E-mail: cellsonic.beauty@gmail.com

Received: December 22, 2017; Accepted: January 05, 2018; Published: January 09,2018 